\title{
Hubungan Ekspresi Protein 16 (p16) dengan Derajat Histopatologik dan Invasi Perineural pada Karsinoma Sel Skuamosa Kepala dan Leher
}

Zulda Musyarifah ${ }^{1}$, Salmiah Agus $^{2}$, Yenita $^{2}$, Hardisman $^{3}$

\begin{abstract}
Abstrak
Protein 16 (p16) merupakan salah satu protein supresor tumor yang memiliki peran dalam patogenesis Karsinoma Sel Skuamosa (KSS) kepala dan leher. Peran protein ini berbeda sesuai dengan faktor risiko paparan karsinogen dan memiliki implikasi terhadap faktor prognostik patologik. Tujuan: Menentukan hubungan protein 16 dengan derajat histopatologik dan Invasi Perineural (IPN) pada KSS kepala dan leher. Metode: Penelitian ini merupakan cross-sectional study dengan sampel sebanyak 60 kasus KSS kepala dan leher yang telah didiagnosis di Laboratorium Patologi Anatomik RSUP Dr. M. Djamil Padang periode Januari 2016 sampai Desember 2018. Sampel diperoleh secara simple random sampling dari blok parafin yang berasal dari jaringan tumor. Dilakukan penilaian ulang pada slaid histopatologik untuk menilai derajat histopatologik dan invasi perineural. Ekspresi p16 pada sel tumor dilihat dengan pulasan imunohistokimia. Korelasi dilakukan analisis statistik bivariat menggunakan uji Chi-square dengan tingkat kemaknaan p<0,05. Hasil: Ekspresi p16 positif didapatkan pada 24 kasus (40\%) dengan kasus terbanyak pada KSS kepala dan leher derajat tinggi, sedangkan pada 36 kasus (60\%) tidak terdapat ekspresi p16. Ekspresi p16 positif memiliki hubungan yang bermakna dengan derajat histopatologik $(p=0,002)$ namun tidak terdapat hubungan antara ekspresi p16 dengan IPN $(p=1,000)$. Simpulan: Ekspresi p16 positif berhubungan dengan derajat histopatologik tumor yang lebih tinggi namun p16 tidak tidak berhubungan dengan kejadian invasi perineural pada KSS kepala dan leher.
\end{abstract}

Kata kunci: derajat histopatologik, ekspresi p16, invasi perineural, KSS kepala dan leher

\begin{abstract}
Protein 16 (p16) is a tumor suppressor protein that has a role in the pathogenesis of Head and Neck Squamous Cell Carcinoma (HNSCC). The role of this protein differs according to the carcinogen exposure and have an implication in pathological prognostic factors. Objectives: To determined the correlation of $p 16$ with the degree of histopathology and perineural invasion (PNI) in HNSCC. Methods: This research was a cross-sectional study with a sample of 60 cases of HNSCC that had been diagnosed at the Anatomical Pathology Laboratory Dr. M. Djamil Hospital Padang from January 2016 to December 2018. Samples were obtained by simple random sampling from formalin fixed paraffin embedded (FFPE) of the tumor tissue. Histopathological was re-evaluated to assess the degree of histopathology and perineural invasion. Expressions of 16 in tumor cells were determined by immunohistochemical staining. Chi-square test was used to determine the correlation with significance level $p<0.05$. Results: There were positive p16 expression in 24 cases (40\%) with the most cases in high-grade HNSCC, while in 36 cases (60\%), there was no p16 expression. Positive $p 16$ expression has a significant correlation with the degree of histopathology $(p=0.002)$, but there was no relationship between $p 16$ expression and PNI $(p=1,000)$. Conclusion: The positive $p 16$ expression was correlated with a higher degree of tumor histopathology, but $p 16$ did not correlate with the incidence of perineural invasion in HNSCC.
\end{abstract}

Keywords: degree of histopathology, p16 expression, HNSCC, perineural invasion 
Affiliasi penulis: ${ }^{1}$ Program Pendidikan Dokter Spesialis Patolog Anatomi, Fakultas Kedokteran, Universitas Andalas, Indonesia ${ }^{2}$ Bagian Patologi Anatomi, Fakultas Kedokteran, Universitas Andalas, Indonesia. ${ }^{3}$ Bagian IImu Kesehatan Masyarakat, Fakultas Kedokteran, Universitas Andalas, Indonesia.

Korespondensi: Zulda Musyarifah,Email:zulda_lubis@yahoo.com Telp: 081363487695

\section{PENDAHULUAN}

Insiden kanker kepala dan leher berada di urutan ke-tujuh dari seluruh kanker yang paling sering ditemukan di dunia yaitu sekitar $5 \%$ dari seluruh kasus kanker dengan angka kematian yang tinggi di negara berkembang. ${ }^{1}$ Pada negara berkembang, kanker kepala dan leher merupakan salah satu kanker terbanyak terutama di Asia. Estimasi data menunjukkan bahwa insiden seluruh kanker kepala dan leher di Indonesia tahun 2018 adalah 27.790 pasien baru dengan prevalensi $72.821{ }^{2}$ Kanker ini tiga kali lebih banyak terjadi pada laki-laki dibandingkan dengan perempuan. ${ }^{1}$

Epidemiologi karsinoma sel skuamosa (KSS) kepala dan leher telah berubah secara signifikan dalam beberapa dekade terakhir. Perubahan ini berupa penurunan insiden KSS kepala dan leher yang diakibatkan rokok sedangkan insiden KSS berkaitan dengan human papillomavirus (HPV) mengalami kenaikan yang drastis. ${ }^{3}$

Ekspresi lebih dari protein 16 (p16) telah dilaporkan berhubungan dengan infeksi HPV dan protein ini telah digunakan sebagai biomarker prediktif untuk HPV tipe risiko tinggi meskipun peningkatan ekspresi p16 tidak selalu eksklusif disebabkan oleh infeksi HPV akan tetapi pemeriksaan imunohistokimia (IHK) p16 telah ditetapkan sebagai penanda pengganti adanya infeksi HPV pada KSS kepala dan leher. ${ }^{4}$

Protein 16 merupakan cyclin dependent kinase inhibitor (CDKI) yang mengontrol umpan balik negatif terhadap siklus sel. Protein ini mengurangi laju siklus sel dengan menginaktivasi komplek cyclin-protein kinase yang spesifik seperti cyclin-dependent kinases (CDK) tipe D1 (CCND1), CDK4, dan CDK6. ${ }^{5}$ Alterasi pada protein ini akan menyebabkan terjadi gangguan pada siklus sel menjadi tidak terkontrol. Pada KSS kepala dan leher terdapat perbedaan ekpresi p16 pada KSS kepala dan leher memberikan simpulan bahwa terdapat perbedaan entitas serta karakteristik klinikopatologik kanker ini. Sebuah penelitian oleh Ralli et al, menyebutkan bahwa ekspresi lebih dari p16 lebih banyak ditemukan pada pasien tidak merokok dan minum alkohol, berhubungan kuat dengan banyaknya partner seksual, derajat histopatologik yang buruk serta peningkatan metastasis ke kelenjar getah bening (KGB). ${ }^{6}$

Derajat histopatologik adalah tingkat diferensiasi secara kuantitatif dengan menggunakan kriteria histologik yang dibagi menjadi diferensiasi baik, sedang, buruk dan tidak berdiferensiasi. Penilaian ini berdasarkan kriteria derajat diferensiasi, polimorfisme sel dan pleomorfisme inti serta aktivitas mitosis. Dalam diagnosis KSS, informasi derajat histopatologik penting dicantumkan karena merupakan salah satu faktor prognosis secara histopatologik yang dihubungkan dengan luaran pasien. Derajat histopatologik merupakan salah satu faktor prediktor yang signifikan terhadap angka rekurensi tumor dan locoregional failure (LRF). ${ }^{7}$

Sebagian besar kematian KSS kepala dan leher disebabkan oleh tingginya angka rekurensi lokoregional. Salah satu faktor yang memengaruhi rekurensi lokal adalah adanya pertumbuhan tumor perineural yaitu invasi perineural (IPN) dan perineural spread (PNS). Invasi perineural adalah proses berjalannya sel kanker menuju serabut saraf dan biasanya dihubungkan dengan serabut saraf yang kecil. Gambaran IPN hanya bisa dievaluasi melalui pemeriksaan histopatologik sedangkan PNS adalah sel tumor yang telah bermigrasi dari lokasi primer, berjalan sepanjang serabut saraf dan dapat dilihat dengan pemeriksaan pencitraan. ${ }^{8}$ Proses terjadinya IPN masih belum banyak diketahui dan melibatkan berbagai macam faktor meliputi the perineural niche. ${ }^{9}$

Daerah kepala dan leher merupakan tempat yang memiliki banyak jaringan serabut saraf dan merupakan salah satu kanker yang memiliki kecenderungan yang tinggi untuk terjadinya IPN. ${ }^{10}$ Invasi perineural dihubungkan dengan prognosis yang buruk meliputi peningkatan risiko untuk rekurensi lokal meskipun dengan reseksi bedah yang komplit (dengan batas sayatan bebas tumor), metastasis ke KGB regional dan angka ketahanan hidup yang lebih buruk. $^{11}$ 
Fungsi utama p16 sebagai regulator siklus sel, tetapi juga memiliki peran dalam proses lainnya seperti apoptosis, invasi sel dan angiogenesis. ${ }^{12}$ Berbagai peranan p16 dalam meregulasi berbagai molekul ini memungkinkan terdapat hubungan antara ekspresi p16 dengan kejadian IPN pada KSS kepala dan leher.

\section{METODE}

Penelitian ini adalah penelitian observasional dengan desain cross sectional study. Sampel penelitian sebanyak 60 kasus diambil secara simple random sampling. Kriteria sampel yaitu kasus KSS kepala dan leher (kecuali lokasi nasofaring) yang diperoleh melalui tindakan biopsi dan/atau eksisi dan telah didiagnosis secara histopatologik di Laboratorium Patologi Anatomik RSUP Dr. M. Djamil Padang serta memiliki kelengkapan data, slaid hematoksilin-eosin ( $\mathrm{HE})$ dan blok parafin. Blok parafin yang mengandung lebih dari $30 \%$ sel tumor yang viable selanjutnya digunakan untuk pemeriksaan pulasan IHK p16. ${ }^{13}$

Slaid HE dilakukan evaluasi untuk menilai derajat histopatologik dan IPN. Derajat histopatologik dinilai berdasarkan klasifikasi WHO 2017. ${ }^{14}$ Tumor dengan diferensiasi baik dikelompokkan menjadi derajat rendah sementara tumor dengan diferensiasi sedang, buruk dan tidak berdiferensiasi dikelompokkan menjadi derajat tinggi. Invasi perineural positif jika terdapat sel-sel tumor yang berada di dalam, sepanjang atau mengelilingi minimal sepertiga (33\%) dari serabut saraf. ${ }^{15}$

\section{Pulasan Imunohistokimia}

Ekspresi p16 dilihat melalui pulasan IHK dengan teknik streptoavidin-biotin imunuperoksidase dan dibuat dari spesimen blok parafin yang dipotong setebal $4 \mu \mathrm{m}$. Antibodi primer p16 berupa antibodi monoklonal (Rabbit, merk Abclonal, USA) dengan pengenceran 1:100. Ekspresi p16 positif jika didapatkan warna coklat pada inti sel dan sitoplasma.

\section{Analisis Ekspresi p16}

Ekspresi p16 yang positif berupa intensitas dan persentase warna coklat pada inti sel dan sitoplasma. ${ }^{16}$ Nilai 0 jika tidak ada sel tumor yang terwarnai atau terwarnai pada membran sel dan/atau stroma, nilai +1 jika sel tumor terwarnai $<70 \%$ (fokal dan/atau tersebar) pada inti sel dan/atau sitoplasma dengan intensitas ringan-kuat, nilai +2 jika sel tumor terwarnai $\geq 70 \%$ secara difus pada inti dan/atau sitoplasma dengan intensitas ringan-sedang dan nilai +3 jika sel tumor terwarnai $\geq 70 \%$ secara difus pada inti sel dan/atau sitoplasma dengan intensitas kuat. Ekspresi p16 negatif jika nilai 0 atau +1 sedangkan nilai +2 dan +3 dikategorikan sebagai ekspresi p16 positif.

Penelitian ini dilakukan setelah mendapat persetujuan dari Komite Etika Penelitian Fakultas Kedokteran Universitas Andalas Nomor: 019/KEP/FK/2020.

\section{HASIL}

\section{Karakteristik Klinikopatologik Pasien KSS Kepala dan Leher}

Kelompok umur terbanyak kasus KSS kepala dan leher adalah umur dekade diatas lima yaitu sebesar $71,6 \%$. Kelompok umur paling sedikit adalah umur $\leq 30$ tahun yaitu sebanyak 2 kasus (3,3\%) dengan rata-rata usia 56,77 $\pm 11,75$ tahun (standar deviasi) dan interval usia antara 16-74 tahun. Jenis kelamin laki-laki lebih banyak ditemukan dibandingkan perempuan sebesar $81,7 \%$ dan $18,3 \%$ dengan perbandingan empat banding satu.

Separuh dari sampel dengan ukuran setara T4 (50\%). Sebagian besar tanpa keterlibatan Kelenjar Getah Bening (KGB) 75\%. Semua sampel tanpa adanya metastasis jauh. Tumor terbanyak berlokasi di daerah hipofaring dan laring (58,3\%) diikuti oleh rongga hidung dan sinus paranasal serta rongga mulut serta lidah dan bibir (20\%) dan orofaring (1,7\%).

Hampir keseluruhan dari sampel gambaran histopatologik KSS konvensional (93,2\%). Derajat diferensiasi paling banyak ditemukan dengan diferensiasi sedang $(41,7 \%)$. Invasi perineural hanya ditemukan pada sebagian kecil sampel sebanyak 8 kasus (15\%) dan ekspresi p16 positif ditemukan pada 24 sampel (40\%). 
Tabel 1. Karakteristik klinikopatologik pasien KSS kepala dan leher

\begin{tabular}{|c|c|c|}
\hline \multirow[t]{2}{*}{ Karakteristik } & \multicolumn{2}{|c|}{ Total } \\
\hline & $(n=60)$ & $\%$ \\
\hline \multicolumn{3}{|l|}{ Umur } \\
\hline$\leq 30$ tahun & 2 & 3,3 \\
\hline 31-40 tahun & 4 & 6,8 \\
\hline 41-50 tahun & 11 & 18,3 \\
\hline $51-60$ tahun & 17 & 28,3 \\
\hline$>60$ tahun & 26 & 43,3 \\
\hline \multicolumn{3}{|l|}{ Jenis Kelamin } \\
\hline Laki-laki & 49 & 81,7 \\
\hline Perempuan & 11 & 18,3 \\
\hline \multicolumn{3}{|l|}{$\mathrm{T}$ (ukuran tumor) } \\
\hline T1 & 2 & 3,3 \\
\hline $\mathrm{T} 2$ & 8 & 13,4 \\
\hline T3 & 20 & 33,3 \\
\hline T4 & 30 & 50,0 \\
\hline \multicolumn{3}{|l|}{$\mathrm{N}$ (status kgb) } \\
\hline Ada & 15 & 25,0 \\
\hline Tidak ada & 45 & 75,0 \\
\hline \multicolumn{3}{|l|}{ Metastasis (M) } \\
\hline Ada & - & - \\
\hline Tidak ada & 60 & 100 \\
\hline \multicolumn{3}{|l|}{ Lokasi tumor } \\
\hline Rongga hidung \& Sinus Paranasal & 12 & 20,0 \\
\hline Rongga mulut, lidah \& bibir & 12 & 20,0 \\
\hline Orofaring & 1 & 1,7 \\
\hline Hipofaring dan Laring & 35 & 58,3 \\
\hline \multicolumn{3}{|l|}{ Varian } \\
\hline Konvensional & 56 & 93,2 \\
\hline Adenosquamous SCC & 1 & 1,7 \\
\hline Acantholytic SCC & 1 & 1,7 \\
\hline Basaloid SCC & 1 & 1,7 \\
\hline Papillary SCC & 1 & 1,7 \\
\hline \multicolumn{3}{|l|}{ Derajat diferensiasi } \\
\hline Diferensiasi baik & 22 & 36,6 \\
\hline Diferensiasi sedang & 25 & 41,6 \\
\hline Diferensiasi buruk & 9 & 15,0 \\
\hline Tidak berdiferensiasi & 4 & 6,8 \\
\hline \multicolumn{3}{|l|}{ Invasi Perineural } \\
\hline Positif & 8 & 13,3 \\
\hline Negatif & 52 & 86,7 \\
\hline \multicolumn{3}{|l|}{ Ekspresi P16 } \\
\hline 0 & 29 & 48,3 \\
\hline+1 & 7 & 11,7 \\
\hline+2 & 10 & 16,7 \\
\hline+3 & 14 & 23,3 \\
\hline
\end{tabular}

\section{Hubungan Ekspresi p16 dengan Derajat Histopatologik KSS Kepala dan Leher}

Hubungan ekspresi p16 dengan derajat histopatologik KSS kepala dan leher dapat dilihat pada Tabel 2.

Tabel 2. Hubungan Ekspresi p16 dengan Derajat Histopatologi KSS Kepala dan Leher

\begin{tabular}{|c|c|c|c|c|c|}
\hline \multirow[t]{2}{*}{$\begin{array}{c}\text { Ekspresi } \\
\text { p16 }\end{array}$} & \multicolumn{2}{|c|}{$\begin{array}{c}\text { Derajat } \\
\text { Histopatologi }\end{array}$} & \multirow[t]{2}{*}{$\begin{array}{c}n \\
(\%)\end{array}$} & \multirow{2}{*}{$\begin{array}{c}\text { OR } \\
(95 \% \\
\mathrm{Cl})\end{array}$} & \multirow[t]{2}{*}{$p$} \\
\hline & $\begin{array}{c}\text { Derajat } \\
\text { Tinggi } \\
\mathrm{f}(\%)\end{array}$ & $\begin{array}{c}\text { Derajat } \\
\text { Rendah } \\
\text { f (\%) }\end{array}$ & & & \\
\hline Positif & $\begin{array}{c}21 \\
(87,5)\end{array}$ & $\begin{array}{c}3 \\
(12,5)\end{array}$ & $\begin{array}{c}24 \\
(100)\end{array}$ & $\begin{array}{r}7,82 \\
(1,97-\end{array}$ & 0,002 \\
\hline Negatif & $\begin{array}{c}17 \\
(47,3)\end{array}$ & $\begin{array}{c}19 \\
(52,7)\end{array}$ & $\begin{array}{c}36 \\
(100)\end{array}$ & $30,95)$ & \\
\hline Total & $\begin{array}{c}38 \\
(63,3)\end{array}$ & $\begin{array}{c}22 \\
(36,7)\end{array}$ & $\begin{array}{c}60 \\
(100)\end{array}$ & & \\
\hline
\end{tabular}

Pada tabel diatas memperlihatkan derajat histopatologik tinggi KSS kepala dan leher lebih besar pada ekspresi p16 positif (87,5\%) dibandingkan dengan ekspresi p16 negatif (47,3\%). Secara statistik, terdapat hubungan bermakna antara ekspresi p16 dengan derajat histopatologik dengan nilai $p=0,002$ dan OR sebesar 7,82 $(\mathrm{Cl}=1,97-30,95)$ yang berarti KSS kepala dan leher dengan ekspresi p16 positif memiliki kemungkinan tujuh kali lebih besar dengan gambaran mikroskopik berupa KSS derajat tinggi dibandingkan dengan KSS kepala dan leher dengan ekspresi $\mathrm{p} 16$ negatif. 


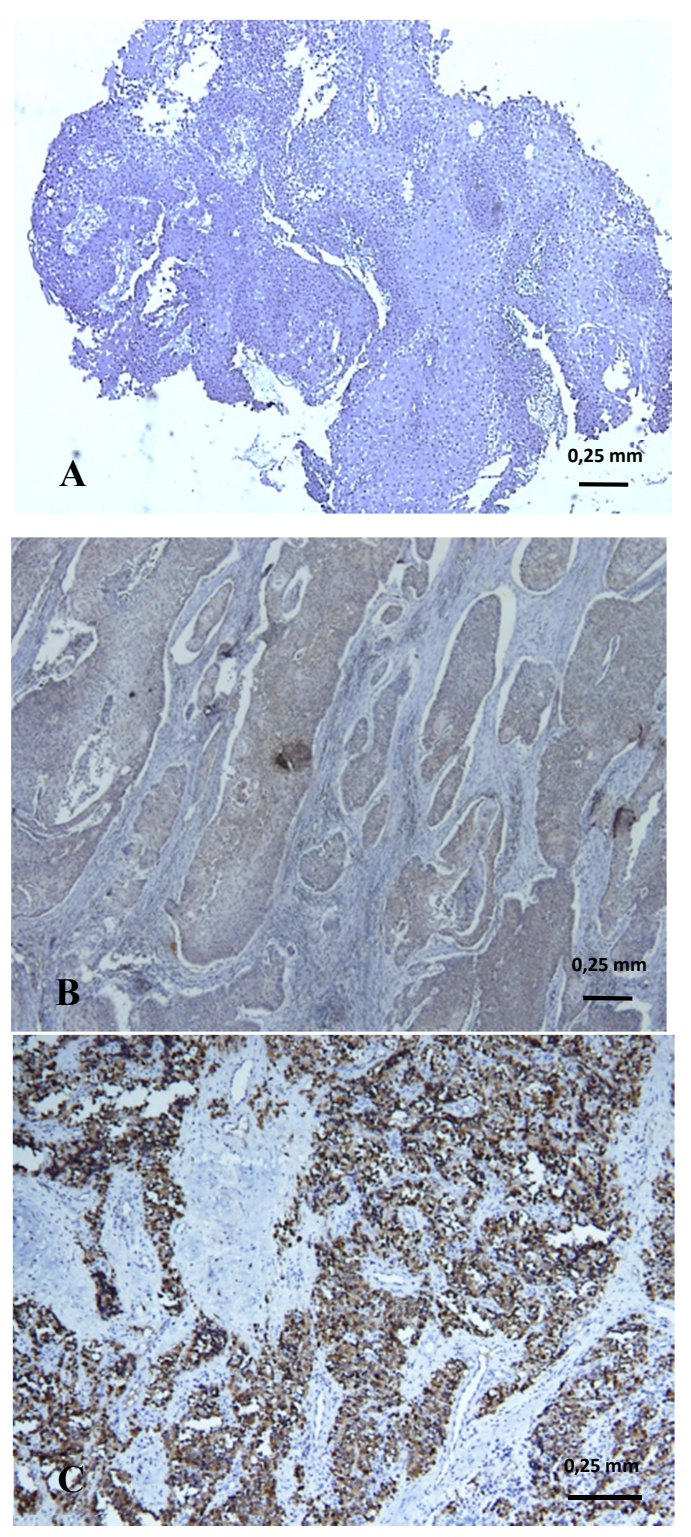

Gambar 1. Hasil pewarnaan IHK p16 berdasarkan derajat histopatologi. A. Negatif, tumor derajat rendah (diferensiasi baik). B. Positif, ekspresi p16 dengan skor +2 pada tumor derajat tinggi (diferensiasi sedang). C. Positif, ekspresi p16 dengan skor +3 pada tumor derajat tinggi (diferensiasi buruk).

Pada penelitian ini dapat dilihat bahwa terdapat variasi hasil pewarnaan IHK p16 positif berupa warna coklat yang difus pada sel tumor dengan perbedaan intensitas pewarnaan dari ringan sampai kuat. Selain itu terdapat variasi hasil pewarnaan IHK p16 dengan derajat histopatologi KSS kepala dan leher (Gambar 1).

\section{Hubungan Ekspresi p16 dengan Invasi Perineural KSS Kepala dan Leher}

Hubungan Ekspresi p16 dengan IPN KSS kepala dan leher dapat dilihat pada Tabel 3.

Tabel 3. Hubungan ekspresi p16 dengan invasi perineural pada Kss kepala dan leher

\begin{tabular}{|c|c|c|c|c|c|}
\hline \multirow{2}{*}{$\begin{array}{c}\text { Ekspresi } \\
\text { p16 }\end{array}$} & \multicolumn{2}{|c|}{ Invasi perineural } & \multirow{2}{*}{$\begin{array}{c}n \\
(\%)\end{array}$} & \multirow{2}{*}{$\begin{array}{c}\text { OR } \\
(95 \% \mathrm{Cl})\end{array}$} & \multirow[t]{2}{*}{$\mathbf{p}$} \\
\hline & $\begin{array}{c}\text { Positif } \\
\text { f (\%) }\end{array}$ & $\begin{array}{c}\text { Negatif } \\
\text { f (\%) }\end{array}$ & & & \\
\hline \multirow[t]{2}{*}{ Positif } & 3 & 2 & 24 & 0,88 & 1,000 \\
\hline & $(12,5)$ & $(87,5)$ & $(100)$ & $(0,19-4,11)$ & \\
\hline \multirow[t]{2}{*}{ Negatif } & 5 & 31 & 36 & & \\
\hline & $(13,9)$ & $(86,1)$ & $(100)$ & & \\
\hline \multirow[t]{2}{*}{ Total } & 8 & 52 & 60 & & \\
\hline & $(13,3)$ & $(86,7)$ & $(100)$ & & \\
\hline
\end{tabular}

Invasi perineural pada KSS kepala dan leher sebanding antara ekspresi p16 positif $(12,5 \%)$ dengan ekspresi p16 negatif (13,9\%). Secara statistik, tidak terdapat hubungan antara ekspresi p16 dengan invasi perineural dengan nilai $p=1,000$ dan $\mathrm{OR} 0,88(\mathrm{Cl}=$ 0,19 - 4,11). Gambar 2 memperlihatkan adanya IPN klasifikasi Liebig tipe $B$ berupa sel tumor yang mengelilingi serabut saraf pada KSS kepala dan leher dengan ekspresi p16 negatif.

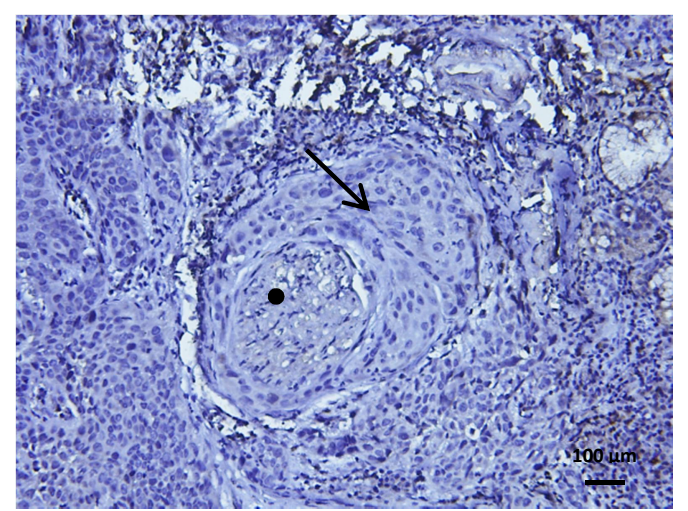

Gambar 2. Gambaran IPN pada KSS kepala dan leher dengan ekspresi p16 negatif (lingkaran: serabut saraf, tanda panah: sel tumor).

\section{PEMBAHASAN}

Analisis Hubungan Ekpresi p16 dengan Derajat Histopatologi KSS Kepala dan Leher

Derajat histopatologi adalah tingkat diferensasi kuantitatif dengan menggunakan kriteria histologi. Pada diagnosis rutin dan penelitian tentang KSS 
kepala dan leher, pemakaian sistem penderajatan secara histologi dipakai untuk memprediksi perilaku tumor. Akan tetapi masih terdapat kontroversi pada literatur tentang nilai prognostik tersebut. ${ }^{11}$

Pada penelitian ini, ekspresi p16 memiliki korelasi yang signifikan dengan derajat histopatologi KSS kepala dan leher $(p=0,002)$. Derajat histopatologi tumor dibagi menjadi derajat tinggi dan derajat rendah dan didapatkan hasil masing-masing sebesar $63,3 \%$ dan $36,7 \%$. Tumor diferensiasi baik diklasifikasikan menjadi derajat rendah dan tumor dengan diferensiasi sedang, buruk dan tidak berdiferensiasi dimasukkan menjadi derajat tinggi. Hal ini sesuai dengan penelitian yang dilakukan oleh Vukelic et al, dimana nilai dari indeks proliferasi Ki-67 meningkat sejalan dengan derajat diferensiasi, dimana tumor dengan diferensiasi sedang dan buruk memiliki indeks proliferasi Ki-67 yang lebih tinggi. ${ }^{17}$

Hasil penelitian ini sejalan dengan penelitian Ralli et al, dimana didapatkan bahwa ekspresi p16 berkorelasi dengan derajat histopatologi tumor $(p=$ 0,002). ${ }^{6}$ Tak jauh berbeda dengan studi oleh Smith et al, $(p=0,02)$ dan Muirhead et al, $(p=0,001)$ yang mendapatkan hasil bahwa ekspresi p16 positif lebih cenderung terdapat pada KSS kepala dan leher dengan stadium yang lebih tinggi dan derajat histopatologi yang lebih buruk. ${ }^{18,19}$

Pada proses karsinogenesis KSS kepala dan leher setidaknya terdapat empat proses yang melibatkan banyak alterasi gen, protein serta molekul lainnya yaitu proses proliferasi sel yang tidak terkontol, diferensiasi sel epitel skuamosa, survival dan proses invasi serta metastasis. ${ }^{20}$ Protein 16 memiliki peran dalam proses proliferasi sel dan kemungkinan ekspresi lebih dari protein tersebut dipengaruhi oleh faktor risiko yang mendasarinya serta memiliki efek pada diferensiasi sel epitel skuamosa. Pada proses morfogenesis sel epitel skuamosa normal pada mukosa saluran pernafasan atas orang dewasa dikontrol oleh gen TP63 dan NOTCH 1. Keratinosit pada lapisan basal merupakan sel epitel skumosa imatur yang mempertahankan potensi proliferatif serta mengekspresikan penanda sel basal (seperti keratin 5/14). Ekspresi dari Keratin 5/14 (K5/14) akan menghasilkan diferensiasi terminal menjadi sel-sel dari lapisan spinosum (K1/10) dan lapisan granular. Pada beberapa sel punca di lapisan basal akan mengalami diferensiasi terminal melalui abnormal cell division. Bila terdapat proliferasi abnormal akan dilindungi terutama melalui proses differentiation-associated cell cycle exit dan apoptosis. ${ }^{20}$ Apabila terjadi alterasi gen yang menyebabkan proliferasi abormal pada berbagai jenis sel ini akan membuat perbedaan dalam derajat diferensiasi KSS kepala dan leher.

Kontrol dalam proses proliferasi dan siklus sel sangat ketat, dimana jika ada gangguan dalam proses tersebut akan menyebabkan proses proliferasi sel yang tidak terkontrol. Bentuk hipofosforilasi dari pRb akan menjaga sel dari perpindahan cek poin G1 dengan mensekuestrasi faktor transkripsi seperti E2F. E2F ini sangat penting dan dibutuhkan dalam mengaktivasi gen fase $\mathrm{S}$. Fosforilasi dari pRb ini dapat terjadi apabila $\mathrm{pRb}$ terikat dengan kompleks CDK1 sehingga mendorong sel berpindah dari fase $\mathrm{G} 1$ menjadi fase $\mathrm{S}$. Protein 16 inilah yang menghambat komplek CDK sehingga berkurangnya jumlah $\mathrm{pRb}$ yang terfosforilasi menyebabkan siklus sel terhenti di fase $\mathrm{G} 1$ dan proliferasi sel dapat terkontrol. Inaktivasi p16 melalui berbagai mekanisme termasuk delesi homozigot, single base-pair mutation dan metilasi gen promotor akan menyebabkan perubahan dalam siklus sel. $^{19}$

Pada infeksi HPV, virus akan menginfeksi sel keratinosit primitif/imatur pada lapisan basal akibat dari mikro trauma seperti abrasi epitel mukosa yang dapat mengekspos membran basal dan sel basal. Bahkan pada orofaring, virus ini dapat masuk melalui kripta epitelium dan menginfeksi lapisan basal tanpa memerlukan adanya jejas pada bagian permukaan epitel. $^{21}$ Setelah menginfeksi sel basal, DNA virus akan bereplikasi dan dapat melakukan siklus sel serta mengamplifikasi sejumlah viral copy menjadi sekitar 50-100 copy pada satu sel. Sel yang terinfeksi akan meninggalkan kompartemen primitif dan memasuki kompartemen proliferasi epitelium (di lapisan spinosum dan granulosum). Pada tempat ini terjadi fase plasmid maintenance, dimana virus dan sel bereplikasi bersama. Human papilloma virus tipe risiko tinggi memiliki gen E6 dan E7. Gen E7 HPV dapat berikatan dengan $\mathrm{pRb}$ yang belum terfosforilasi sehingga sel bisa melewati cek poin $\mathrm{G} 1$ masuk ke fase S siklus sel, sementara gen E6 mengikat p53 dan 
melakukan ubiquitinisasi protein ini. Kombinasi tersebut menyebabkan siklus sel berlangsung abnormal dan menyebabkan sel terlepas dari kontrol siklus sel dan terjadi transformasi keganasan. ${ }^{22}$ Kedua proses ini juga dapat mengakibatkan peningkatan ekpresi p16 sebagai umpan balik negatif akibat tidak adanya $\mathrm{pRb}$ yang dapat mengontrol siklus sel, sehingga ekspresi lebih dari p16 dianggap sebagai penanda pengganti infeksi HPV. Hal ini kemungkinan yang menyebabkan bahwa KSS kepala dan leher dengan ekspresi p16 positif lebih banyak ditemukan pada tumor dengan derajat histopatologi yang buruk. Meskipun begitu peningkatan ekspresi p16 pada KSS kepala dan leher tidak selalu identik dengan infeksi HPV. Kekurangan pada penelitian ini adalah tidak dilakukan pemeriksaan lanjutan untuk memastikan adanya infeksi HPV. Sehingga pada sampel dengan ekspresi p16 positif belum bisa dipastikan apakah KSS tersebut memang betul akibat dari proses karsinogenesis virus atau karena alterasi jalur lain yang menyebabkan peningkatan p16. Untuk itu perlu dilakukan pemeriksaan lebih lanjut untuk mendeteksi DNA HPV melalui pemeriksaan lainnya seperti pemeriksaan PCR, in situ hybridization (ISH), dan southern blotting. ${ }^{23}$

Perbedaan ini bisa disebabkan oleh karena perbedaan ukuran sampel, distribusi lokasi tumor, perbedaan kriteria skoring dan tipe antibodi yang digunakan.

\section{Analisis Hubungan Ekpresi p16 dengan IPN pada KSS Kepala dan Leher}

Pertumbuhan perineural adalah sebuah jalur yang unik dalam proses metastasis keganasan dan dihubungkan dengan prognosis yang buruk. Invasi tumor ke serabut saraf dapat dilihat dengan pemeriksaan secara histopatologi atau pencitraan. Sampai saat ini belum banyak diketahui mekanisme secara molekuler yang mendasari proses ini. Istilah IPN merupakan istilah patologi yang hanya dapat dilihat melalui pemeriksaan mikroskopik berupa invasi sel tumor pada perineural atau endoneural. ${ }^{8}$ Adapun istilah perineural spread (PNS) mengacu pada sel tumor yang telah bermigrasi dari lokasi primer dan 'berjalan' sepanjang serabut saraf. Kelainan ini dapat terlihat melalui pemeriksaan pencitraan. ${ }^{8}$
Pada penelitian ini didapatkan IPN sebanyak $13,3 \%$ kasus dimana analisis statistik hubungan antara ekspresi p16 dengan kejadian IPN menunjukkan hasil tidak bermakna. Hal ini memberikan kesimpulan bahwa ekspresi p16 yang berlebih tidak mempengaruhi proses IPN pada KSS kepala dan leher. Hasil yang serupa juga didapatkan oleh Mendelsohn et al, dimana ekspresi p16 tidak memiliki korelasi dengan kejadian IPN maupun invasi perivaskular (IPV) meskipun terdapat hubungan yang signifikan antara ekspresi p16 dan in situ hybridization (ISH) HPV positif dengan keterlibatan KGB regional. ${ }^{24}$ Hal ini merupakan salah satu kemungkinan yang menyebabkan KSS kepala dan leher dengan ekspresi lebih dari p16 memiliki prognosis yang lebih baik karena tidak memiliki kecenderungan untuk terjadinya IPN.

Protein 16 yang seharusnya terdapat pada inti sel juga dapat mengalami sekustrasi ke sitoplasma dan diduga memiliki efek pada proses invasi serta metastasis sel kanker yang telah dibuktikan melalui berbagai penelitian baik secara invitro maupun invivo. $^{12}$ Akan tetapi belum ada penelitian yang menjelaskan hubungan yang jelas antara p16 dengan patogenesis IPN. Salah satu teori menjelaskan bahwa ekspresi p16 dan status HPV positif dihubungkan dengan peningkatan ekspresi dari protein tyrosine kinases (Trk). ${ }^{25}$ Protein Trk memiliki afinitas yang tinggi untuk berikatan dengan nerve growth factor (NGF). Faktor pertumbuhan ini diekspresikan pada berbagai tipe sel tumor dan memiliki peran penting dalam proses IPN seperti survival, diferensiasi sel saraf dan pembentukan akson. ${ }^{9}$ Pada penelitian invitro yang dilakukan oleh Bapat et al, didapatkan bahwa jalur NGF-Trk dapat mempromosikan survival sel kanker dan membantunya melewati dorsal root ganglia. ${ }^{26}$ Ini menjadi salah satu kelemahan dalam penelitian ini, dimana p16 hanya memiliki efek secara tidak langsung terhadap proses terjadinya IPN. Sementara itu terdapat berbagai jalur dan molekul lain yang berperan langsung dalam proses IPN.

Sel kanker pada nerve environment tidak hanya menampilkan perilaku peningkatan proliferasi tapi juga penurunan apoptosis dengan meregulasi gen yang berhubungan dengan jalur nuclear factor $K B$ (NF-kB) dan melakukan downstream serta mensekresikan 
berbagai molekul yang dapat meningkatkan potensi invasi meliputi brain-derived neurotrophic factor (BDNF), nerve growth factor (NGF), neurotrophin-3 (NT-3), neurotrophin-4 (NT-4), glial cell-line derived neurotrophic factor (GDNF), neural cell adhesion molecule (NCAM), substance P (SP), kemokin dan faktor lainnya. Hal ini dapat menyebabkan peningkatan pertumbuhan neurit dari serabut saraf menuju sel kanker dan memudahkan sel kanker berinteraksi dengan serabut saraf. ${ }^{27}$

Penilaian IPN secara patologi dan korelasinya dengan faktor klinis sudah cukup dimengerti akan tetapi proses patogenesis secara molekuler masih belum sepenuhnya dipahami. Hal ini karena proses IPN sendiri adalah proses yang rumit dan melibatkan banyak faktor disekitar sel kanker yang disebut perineural nieche serta keterbatasan teknik untuk mengeksplorasi proses ini. ${ }^{9}$

Pada penelitian ini didapatkan hasil yang tidak bermakna antara ekspresi p16 positif dengan kejadian IPN, akan tetapi adanya IPN penting dicantumkan dalam laporan patologi KSS kepala dan leher karena akan memberikan implikasi dalam prognosis dan terapi selanjutnya. ${ }^{8}$

\section{SIMPULAN}

Terdapat hubungan antara ekpresi p16 positif dengan derajat histopatologik KSS kepala dan leher yaitu ekspresi p16 positif pada KSS kepala dan leher memiliki tampilan mikroskopik tumor derajat tinggi.

Tidak terdapat hubungan antara ekspresi p16 dengan kejadian IPN pada KSS kepala dan leher.

\section{SARAN}

Dokter klinis dapat mempertimbangkan pemeriksaan IHK P16 pada pasien KSS kepala dan leher jika tampilan mikroskopik tumor derajat tinggi pada pasien yang memiliki faktor risiko tinggi. Sampel yang digunakan dalam penelitian KSS kepala dan leher sebaiknya adalah jaringan tumor yang diambil dari reseksi bedah primer. Dalam penelitian selanjutnya untuk memahami patogenesis IPN sebaiknya mengeksplorasi jalur dan molekul lain yang berperan langsung dalam patogenesis IPN.

\section{UCAPAN TERIMA KASIH}

Terima kasih kepada semua pihak yang telah membantu dan terlibat dalam proses penelitian ini.

\section{DAFTAR PUSTAKA}

1. Gupta B, Johnson NW, Kumar N. Global epidemiology of head and neck cancers: A continuing challenge. Oncology. 2016;91(1):13-23.

2. World Health Organization (WHO). Estimated agestandardized incidence rates in 2018 [Internet]. GLOBOCAN. 2018 (diunduh 11 Februari 2019). Tersedia dari: https://gco.iarc.fr/today/home

3. McDermott JD, Bowles DW. Epidemiology of head and neck squamous cell carcinomas: Impact on staging and prevention strategies. Curr Treat Options Oncol. 2019;20(5):1-13.

4. Bryant AK, Sojourner EJ, Vitzthum LK, Zakeri K, Shen H, Murphy JD, et al. Prognostic role of p16 in nonoropharyngeal head and neck cancer. J Natl Cancer Inst. 2018;110:1393-9.

5. Silva SD, Nonogaki S, Soares FA, Kowalski LP, Silva SD, Nonogaki S, et al. p16 ( INK4a ) has clinicopathological and prognostic impact on oropharynx and larynx squamous cell carcinoma p16 ( INK4a ) has clinicopathological and prognostic impact on oropharynx and larynx squamous cell carcinoma. Braz J Med Biol Res. 2012;45(12):1237-333.

6. Ralli M, Singh S, Yadav SP., Sharma N, Verma R, Rajev Sen. Assessment and clinicopathological correlation of p16 expression in head and neck squamous cell carcinoma. J Can Res Ther. 2016;12(1):232-7.

7. Cardesa A, Slootweg PJ. Pathology of the head and neck. Germany: Springer; 2006.

8. Frunza A, Slavescu D, Lascar I. Perineural invasion in head and neck cancers - a review-. J Med Life. 2014;7(2):121-3.

9. Chen S, Zhang B, Zhou B, Zhu C, Sun L, Feng Y. Perineural invasion of cancer: a complex crosstalk between cells and molecules in the perineural niche. Am J Cancer Res. 2019;9(1):1-21.

10. Meng H, Miao S, Chen K, Li H, Yao G, Geng J, et al. Association of $\mathrm{p} 16$ as prognostic factors for 
oropharyngeal cancer: Evaluation of p16 in 1470 patients for a 16 year study in Northeast China. Biomed Res Int. 2018;2018:1-9.

11. El-Naggar AK, Chan JKC, Rubin Grandis J, Takata T, Slootweg PJ. WHO classification of head and neck tumours. Lyon: IARC; 2017.

12. Romagosa C, Simonetti S, López-Vicente L, Mazo A, Lleonart ME, Castellvi J, et al. P16Ink4a overexpression in cancer: A tumor suppressor gene associated with senescence and high-grade tumors. Oncogene. 2011;30(18):2087-97.

13. Lou Y, Diao L, Cuentas ERP, Denning WL, Chen $\mathrm{L}$, Fan $\mathrm{Y}$, et al. Epithelial-mesenchymal transition is associated with a distinct tumor microenvironment including elevation of inflammatory signals and multiple immune checkpoints in lung adenocarcinoma. Clin Cancer Res. 2016; 22 (14): 3630-42.

14. Ampur O, Sudarsa I, Suryawisesa IB. Association of p16 expression with clinicopathological features of oral cavity squamous cell carcinoma patients in Bali. Bali Med J. 2016;5(3):362-6.

15. Liebig C, Ayala G, Wilks JA, Berger DH, Albo D. Perineural invasion in cancer: A review of the literature. Cancer. 2009;115(15):3379-91.

16. Will Z, Ilan C. Equivocal p16 immunostaining in squamous cell carcinoma of the head and neck: staining patterns are suggestive of HPV status. Head Neck Pathol. 2012;6:422-9.

17. Vukelic J, Dobrila-Dintinjana R, Dekanic A, Marijic $B$, Cubranic A, Braut $T$. The relevance of assessing the cell proliferation factor ki-67 in squamous cell carcinoma of the larynx. Biomed Res Int. 2019. Jan 15:1-6.

18. Smith EM, Rubenstein LM, Hoffman $H$, Haugen TH, Turek LP. Human papillomavirus, p16 and p53 expression associated with survival of head and neck cancer. Infect Agents Cancer. 2010;5(4):110.
19. Muirhead DM, Hoffman HT, Robinson RA. Correlation of clinicopathological features with immunohistochemical expression of cell cycle regulatory proteins $\mathrm{p} 16$ and retinoblastoma: Distinct association with keratinisation and differentiation in oral cavity squamous cell carcinoma. J Clin Pathol. 2006;59(7):711-5.

20.Rothenberg SM, Ellisen LW. The molecular pathogenesis of head and neck squamous cell carcinoma. J Clin Invest. 2012;122(6):1951-7.

21. Husain N, Neyaz A. Journal of Oral Biology and Craniofacial Research Human papillomavirus associated head and neck squamous cell carcinoma: Controversies and new concepts. J Oral Biol Craniofacial Res. 2017;7(3):198-205.

22. Stanley MA. Epithelial cell responses to infection with human papillomavirus. Clin Microbiol Rev. 2012;25(2):215-22.

23. Jr JSL, Beadle B, Bishop JA, Chernock RD, Colasacco C, Ascp SCT, et al. Human papillomavirus testing in head and neck. Arch Pathol Lab Med. 2018;142:559-97.

24. Mendelsohn AH, Lai CK, Shintaku IP, Elashoff DA, Dubinett SM, Abemayor E, et al. Histopathologic findings of HPV and p16 positive HNSCC. Laryngoscope. 2010;120:1788-94.

25. Cho YA, Chung JM, Ryu H, Kim EK, Cho BC, Yoon SO. Investigating Trk Protein Expression between Oropharyngeal and Non-oropharyngeal Squamous Cell Carcinoma: Clinical implications and possible roles of human papillomavirus infection. Cancer Res Treat. 2019;51(3):1052-63.

26. Bapat AA, Munoz RM, Von Hoff DD, Han $H$. Blocking nerve growth factor signaling reduces the neural invasion potential of pancreatic cancer cells. PLoS One. 2016;October:1-15.

27. Roh J, Muelleman T, Tawfik O, Thomas SM. Perineural Growth in Head and Neck Squamous Cell Carcinoma: A Review. Oral Oncol. 2016; 51 (1):16-23 